Article

\title{
Time-Gated Luminescent In Situ Hybridization (LISH): Highly Sensitive Detection of Pathogenic Staphylococcus aureus
}

\author{
Nima Sayyadi ${ }^{1,2}, *\left(\mathbb{D}\right.$, Russell E. Connally ${ }^{3}$, Thomas S. Lawson ${ }^{2,3}$, Jingli Yuan ${ }^{4}$, \\ Nicolle H. Packer ${ }^{1,2, *}$ and James A. Piper ${ }^{2,3}$ \\ 1 Department of Molecular Sciences, Macquarie University, Sydney, NSW 2109, Australia \\ 2 ARC Centre of Excellence for Nanoscale Biophotonics (CNBP), Macquarie University, Sydney, NSW 2109, \\ Australia; thomas.lawson@mq.edu.au (T.S.L.); jim.piper@mq.edu.au (J.A.P.) \\ 3 Department of Physics and Astronomy, Macquarie University, Sydney, NSW 2109, Australia; \\ russell.connally@mq.edu.au \\ 4 State Key Laboratory of Fine Chemicals, School of Chemistry, Dalian University of Technology, \\ Dalian 116023, China; jlyuan@dlut.edu.cn \\ * Correspondence: nima.sayyadi@mq.edu.au (N.S.); nicki.packer@mq.edu.au (N.H.P.)
}

Academic Editor: Run Zhang

Received: 14 May 2019; Accepted: 29 May 2019; Published: 31 May 2019

\begin{abstract}
We describe simple direct conjugation of a single TEGylated Europium chelate to DNA that binds to intracellular rRNA and is then detected using a homogeneous luminescent in situ hybridisation (LISH) technique. As a proof-of-principle, Staphylococcus aureus (S. aureus) was selected as a model for our study to show the ability of this probe to bind to intracellular $16 \mathrm{~S}$ ribosomal rRNA. A highly purified Europium chelate conjugated oligonucleotide probe complementary to an rRNA sequence-specific $S$. aureus was prepared and found to be soluble and stable in aqueous solution. The probe was able to bind specifically to $S$. aureus via in situ hybridisation to differentiate S. aureus from a closely related but less pathogenic Staphylococcus species (S. epidermidis). A time-gated luminescent (TGL) microscope system was used to generate the high signal-to-noise ratio (SNR) images of the $S$. aureus. After excitation $\left(365 \mathrm{~nm}\right.$, Chelate $\lambda_{\max }=335 \mathrm{~nm}$ ), the long-lived $\left(\mathrm{Eu}^{3+}\right)$ luminescent emission from the probe was detected without interference from natural background autofluorescence typically seen in biological samples. The luminescent images were found to have 6 times higher SNR or sensitivity compared to the fluorescent images using conventional fluorophore Alexa Fluor 488. The TEGylated Europium chelate -oligo probe stained S. aureus with mean signal intensity 3.5 times higher than the threshold level of signal from S. epidermidis (with SNR 8 times higher). A positive control probe (EUB338-BHHTEGST-Eu ${ }^{3+}$ ) has mean signal intensity for S. aureus and S. epidermidis equally 3.2 times higher than the threshold of signal for a negative NON-EUB338 control probe. The direct conjugation of a single Europium chelate to DNA provides simplicity and improvement over existing bovine serum albumin (BSA)/streptavidin/biotinylated DNA platforms for multi-attachment of Europium chelate per DNA and more importantly makes it feasible for hybridisation to intracellular RNA targets. This probe has great potential for highly sensitive homogeneous in situ hybridisation detection of the vast range of intracellular DNA targets.
\end{abstract}

Keywords: homogeneous luminescent in situ hybridisation; TEGylated Europium chelate; time-gated luminescent microscopy; Staphylococcus aureus (S. aureus) detection

\section{Introduction}

Staphylococci include Staphylococcus aureus (S. aureus) and coagulase-negative Staphylococcus species (CoNS). S. aureus is more virulent and usually causes more serious infections than CoNS [1-3]. 
The ability to rapidly and accurately distinguish between $S$. aureus and non-S. aureus bacteria is essential for the appropriate therapeutic use of antibiotics and timely intervention for infection control in patients. Unfortunately, after Gram staining, the definitive identification of S. aureus involves a number of time-consuming procedures. Traditional methods require subculturing (for 12 to $24 \mathrm{~h}$ ) followed by biochemical analysis. Rapid identification of $S$. aureus would thus be beneficial.

Several molecular methods such as PCR [4-6], nanoparticle DNA-based biosensor [7-10] and the DNA microarray approach [11-15] have been reported for the rapid identification of pathogenic bacteria such as $S$. aureus. However, homogeneous fluorescence in situ hybridisation (FISH) provides inexpensive and rapid identification of $S$. aureus in blood culture samples [16-20]. We have previously reported an improvement to the specificity of fluorescence in situ hybridisation (FISH) detection of S. aureus. This was achieved using a simple and effective permeabilisation technique in conjunction with a conventional fluorescent organic dye, such as Alexa Fluor 488 [21-23]. However, imaging the FISH labelled S. aureus under fluorescent microscopy has two major limitations. Firstly, the fluorescent signal from the organic dye used is rapidly quenched and loses its brightness during its excitation and visualisation. Secondly, the signal from the targeted S. aureus cells overlaps with the naturally high autofluorescence background found in most biological matrixes. As a result, the intensity of the FISH labelled S. aureus (or signal intensity) to background autofluorescence intensity ratio, that is, the signal-to-noise ratio (SNR), is dramatically reduced and consequently decreases the sensitivity of detection.

In comparison to conventional fluorescent organic dyes, lanthanide chelates have unique emission characteristics, including long excited-state lifetime, sharply spiked emission spectra and large Stokes shift. These characteristics, in combination with time-gated luminescence (TGL) microscopy, are advantageous in discriminating target signal against short lived autofluorescence in biological matrixes [24]. The high SNRs which can be achieved with lanthanide-based luminescent probes translate directly to high detection sensitivities, substantially exceeding those achievable with conventional fluorophores and making these luminescent probes an attractive alternative to radio isotope-based probes [25].

$\mathrm{BHHCT}-\mathrm{Eu}^{3+}$ is a tetra-dentate $\beta$-diketone Europium chelate that was synthesised in our research group [26]. It has a strong luminescent emission, a high quantum yield and a long lifetime. Although BHHCT-Eu ${ }^{3+}$ has been used for the TGL detection of a wide range of biotargets, such as Giardia and Cryptosporidium [27], its highly reactive sulfonyl chloride group at the attachment point to biotargets gave it a rather low bioconjugate specificity. It is also highly hydrophobic and prone to precipitation when multiconjugation of chelate per immune-protein is used for bioconjugation. These limitations were addressed by the introduction of a propanyl linker that used a $N$-hydroxysuccinimide ester as the activated attachment point (BHHST-Eu ${ }^{3+}$ )[28]. More recently, it was further modified by the replacement of the propanyl linker of BHHST with a tetra-ethylene glycol (TEG) linker that gives the resultant immune-conjugates (e.g., conjugated antibody) luminescent probe $\left(B H H T E G S T-\mathrm{Eu}^{3+}\right)$ a higher aqueous solubility and stability [29-31].

We have previously shown the successful use of BHHCT chelates in combination with bovine serum albumin (BSA)/streptavidin/biotinylated DNA platforms for the identification of a specific DNA sequence via luminescence resonance energy transfer (LRET) technique in luminescence in situ hybridisation fashion. Intermediate proteins, such as biotin/streptavidin pairs and BSA, were used to provide enhanced labelling of Europium chelate per oligonucleotide probe so as to increase the luminescence emission per DNA and increase detection sensitivity [32,33]. BSA was also added as an intermediate protein and increased the solubility of the BHHCT conjugate, as this chelate is inherently very hydrophobic. However, using the biotin/streptavidin platform and BSA required extra steps in its preparation, conjugation and tuning of the ratio of chelate to protein. For the same reasons, the use of a biotinylated DNA was also necessary. Even so, conjugation of multiple chelates to the intermediate reagent remained susceptible to precipitation and aggregation of the bioconjugate. More importantly, use of streptavidin/biotinylated DNA platforms for conjugation limits the application of luminescence 
in situ hybridisation, particularly for intracellular targets such as rRNA found in bacteria. This is because the large size of the BSA/streptavidin/biotinylated-DNA probe inhibits movement through the permeabilised membrane of bacterial cells.

In this work, we have addressed these limitations by direct conjugation of a single TEGylated Europium chelate (BHHTEGST) [29] to a DNA sequence specific to the intracellular ribosomal 16S rRNA of $S$. aureus [34], for use in a homogeneous luminescence in situ hybridisation (LISH) detection. The BHHTEGST-DNA probe was soluble in aqueous solution and stable throughout experimentation. This single TEGylated Europium-DNA probe labelled S. aureus to produce bright orange-red (Eu ${ }^{3+}$ $615 \mathrm{~nm})$, high-contrast TGL images with high SNR. The robustness of the single Europium chelate conjugated DNA probe was confirmed by the substantially brighter luminescence of $S$. aureus cells compared to the closely related species, S. epidermidis (negative control). S. aureus and S. epidermidis look alike under a microscope and are frequently detected together in the culture of human blood samples $S$. aureus.

Since our first reports of TGL microscopy were published [27,35], we have made many advances that have led to the development of relatively low-cost instrument modules [36,37]. For the present experiments, we used the gated autosynchronous luminescence detector (GALD) that can be fitted to a standard inverted epifluorescence microscope. This setup was used to obtain high-contrast luminescent images of $S$. aureus cells, which were observed to have a SNR nearly 8-fold higher than that seen in the S. epidermidis cells.

\section{Results and Discussion}

Herein we describe the application of a single TEGylated Europium chelate for direct conjugation to short DNA specific to the ribosomal 16S rRNA of S. aureus for selective and highly sensitive detection of $S$. aureus via luminescent in situ hybridisation (LISH).

This luminescent BHHTEGST-Eu ${ }^{3+}$-DNA probe is soluble in water, stable and was successfully hybridised to intracellular rRNA of $S$. aureus to produce bright and high-contrast time-gated luminescence (TGL) images. This single Europium-conjugated DNA probe provides simplicity of preparation and improvement in intracellular targeting via in situ hybridisation over existing BSA/streptavidin/biotinylated DNA platforms.

\subsection{Preparation of Europium Chelate Probes}

BHHTEGST has a succinimide reactive group that was covalently bound to the modified DNA containing a primary amino group at $5^{\prime}$ position using $\mathrm{NaHCO}_{3}$ buffer $(100 \mathrm{mM}, \mathrm{pH} 8.5)$ for incubation for $1 \mathrm{hr}$ at $37^{\circ} \mathrm{C}$. The Europium chelate conjugated to DNA (DNA-BHHTEGST-Eu ${ }^{3+}$ ) described in this work was purified by precipitation of conjugated oligonucleotide in ethanol. We used 20-molar excess of Europium chelate to DNA for the conjugation, and only conjugated oligonucleotide was precipitated and isolated from excess unbound Europium chelate in ethanol solution (as detailed in the experimental section). We also observed that the initial purification of the unconjugated amino modified DNA by precipitation in ethanol was necessary for quantitative conjugation of DNA to the Europium chelate.

Target DNA (SAU69; 5'-G AAG CAA GCT TCT CGT CCG), specific to the ribosomal 16S rRNA of $S$. aureus [34] was conjugated to the Europium chelate (BHHTEGST). This produced SAU69-BHHTEGST, as shown in Figure 1. The DNA-BHHTEGST probes were found to be soluble in aqueous solution and stable throughout experimentation for over one year. The universal nonselective eubacteria probe DNA sequence (EUB338; 5'-G CTG CCT CCC GTA GGA GT) [38] was used as a positive control. It labels both $S$. aureus and $S$. epidermidis bacteria. This probe was applied using the same treatment as that used when the SAU69 LISH was applied. The nonbinding NON-EUB338 probe (NON-EUB338; 5'-C GAC GGA GGG CAT CCT CA), reported by Wallner et al. [39] was used as a negative control. This sequence does not bind to most bacterial ribosomal 16S RNA. 


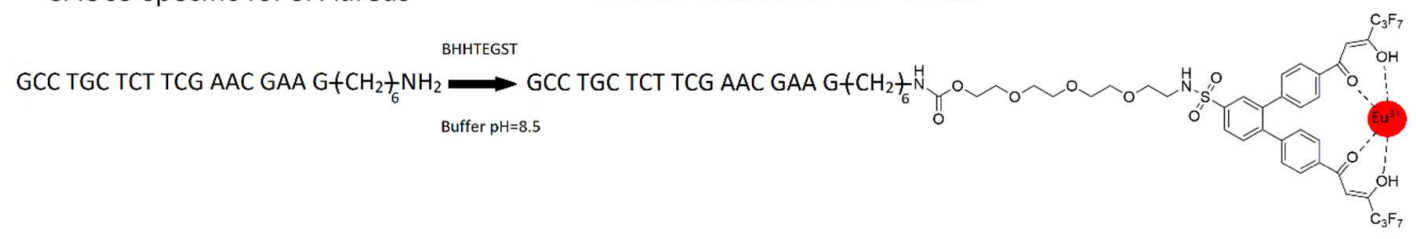

Figure 1. The SAU69 oligonucleotide that has a specificity for hybridisation to the 16S ribosomal RNA of $S$. aureus (with an amino group in $5^{\prime}$ ) was conjugated with Europium chelate (BHHTEGST-Eu ${ }^{3+}$ ) to produce the SAU69-BHHTEGST-Eu ${ }^{3+}$ probe.

After purification of DNA-BHHTEGST by precipitation, a small portion of the conjugated probes was analysed by gel electrophoresis and analytical HPLC. The results from both tests indicated that the conjugation of Europium chelate BHHTEGST with DNA proceeded quantitatively without the presence of unreacted DNAs and so did not require further purification. The results from the HPLC analysis indicated that the conjugated DNA-BHHTEGST were more than $97 \%$ pure. This was confirmed by gel electrophoresis analysis (as described next). The prepared DNA-BHHTEGST conjugate was stored in a freezer (at $-20^{\circ} \mathrm{C}$ ) as the stock probe solution (1.4 $\mathrm{mM}$ in concentration).

Gel electrophoresis was performed to confirm the purity of the conjugated oligonucleotides (DNA-BHHTEGST). Unconjugated DNA was used as a control. Figure 2 (left-hand panel) shows the DNAs (EUB338, NON-EUB338 and SAU69) and their corresponding DNA-BHHTEGST-Eu ${ }^{3+}$ conjugates. Lanes A, C and E are unconjugated DNA tested (A, EUB338; C, NON-EUB338; $\mathrm{E}, \mathrm{SAU} 69)$. Lanes $\mathrm{B}, \mathrm{D}$ and $\mathrm{F}$ are the corresponding DNA-BHHTEGST-Eu ${ }^{3+}$ conjugates $(\mathrm{B}$, EUB338-BHHTEGST-Eu ${ }^{3+}$; D, NON-EUB338-BHHTEGST-Eu ${ }^{3+}$; F, SAU69-BHHTEGST-Eu ${ }^{3+}$ ). On the left-hand panel in Figure 2, DNA traces were visualised under $254 \mathrm{~nm}$ UV light. These include unconjugated DNAs (A, C and E) and their corresponding BHHTEGST conjugates (B, D and E). No unconjugated DNAs (A, C and E) were detected in B, D and F, confirming quantitative conjugation of DNA to BHHTEGST. For the visualisation of the Europium chelate in conjugated oligonucleotides, the same gel was sprayed with a solution of $\mathrm{EuCl}_{3}$. It was then visualised under $365 \mathrm{~nm}$ UV light. This is shown in the right-hand panel in Figure 2. The red Europium (III) emissions of B, D and $\mathrm{F}$, seen as single spots under $365 \mathrm{~nm}$ radiation, confirmed a single pure product from conjugation of BHHTEGST-Eu ${ }^{3+}$ to each DNA oligonucleotide. The results confirmed the high purity of the conjugated oligonucleotides.

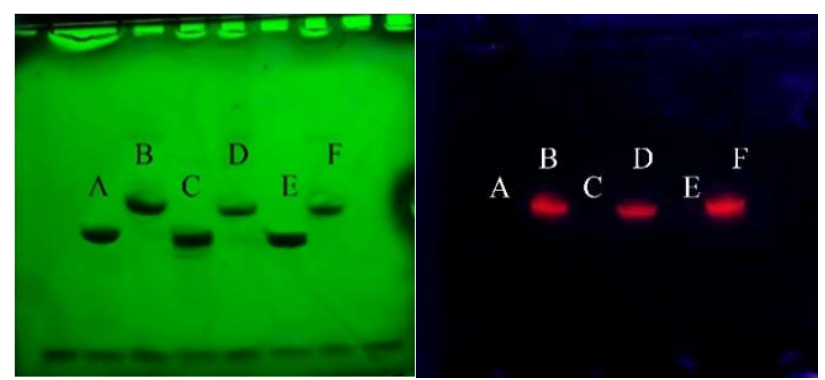

Figure 2. Gel electrophoresis results for EUB338/NON-EUB338/SAU69 DNAs and the corresponding DNA-BHHTEGST-Eu ${ }^{3+}$ conjugates (A, EUB338-DNA; B, EUB338-BHHTEGST-Eu ${ }^{3+}$; C, NON-EUB33 8-DNA; D, NON-EUB338-BHHTEGST-Eu ${ }^{3+}$; E, SAU69-DNA; F, SAU69-BHHTEGST-Eu ${ }^{3+}$ ) are shown. The images in the left-hand panel were illuminated with $254 \mathrm{~nm}$ (both unconjugated and conjugated DNAs absorb at this wavelength). Those in the right-hand panel were illuminated with $365 \mathrm{~nm}$ (only the DNA-BHHTEGST-Eu ${ }^{3+}$ conjugates emit red Europium luminescence at $613 \mathrm{~nm}$ ).

Conjugated oligonucleotides were also analysed by analytical HPLC, and the purity of conjugated DNAs was confirmed according to HPLC chromatograms. As shown in Figure 3, chromatograms A, C and E represent unconjugated DNAs (A, EUB338; C, NON-EUB338; E, SAU69) and the 
chromatograms of B, D and F correspond to DNA-BHHTEGST conjugates (B, EUB338-BHHTEGST; D, NON-EUB338-BHHTEGST; and F, SAU69-BHHTEGST). The HPLC chromatograms of the unconjugated DNAs and conjugated DNAs were obtained at $270 \mathrm{~nm}$ excitation. The HPLC chromatograms of conjugated DNAs (DNA-BHHTEGST) were obtained at both 270 (Figure 3) and $330 \mathrm{~nm}$ (Figures S1-S9) excitation. DNA absorbs light at $270 \mathrm{~nm}$ and the chromophore present in BHHTEGST chelate at $330 \mathrm{~nm}$ wavelength $\left(\lambda_{\max } 335 \mathrm{~nm}\right)$. DNA-BHHTEGST absorption at both $270 \mathrm{~nm}$ and $330 \mathrm{~nm}$ confirmed that chelate was attached to the corresponding DNAs. Trace amounts of unidentified impurities were observed in the chromatogram of free DNAs. These impurities were minimal based on the relative integration value of the chromatograms. Trace impurities were also observed in the HPLC chromatogram of the conjugated DNAs. However, the amount was also negligible. According to the integration calculations obtained from the chromatogram, the average purity of the DNA-BHHTEGST conjugates was above $97 \%$. Note that the Europium (III) ion was not added to the DNA conjugate for HPLC analysis. Through this manuscript, DNA-BHHTEGST refers to conjugated DNA with Europium ligand without addition of Europium (III) ion, and DNA-BHHTEGST-Eu ${ }^{3+}$ refers to the conjugated DNA with Europium chelate that binds the Europium (III) ion.

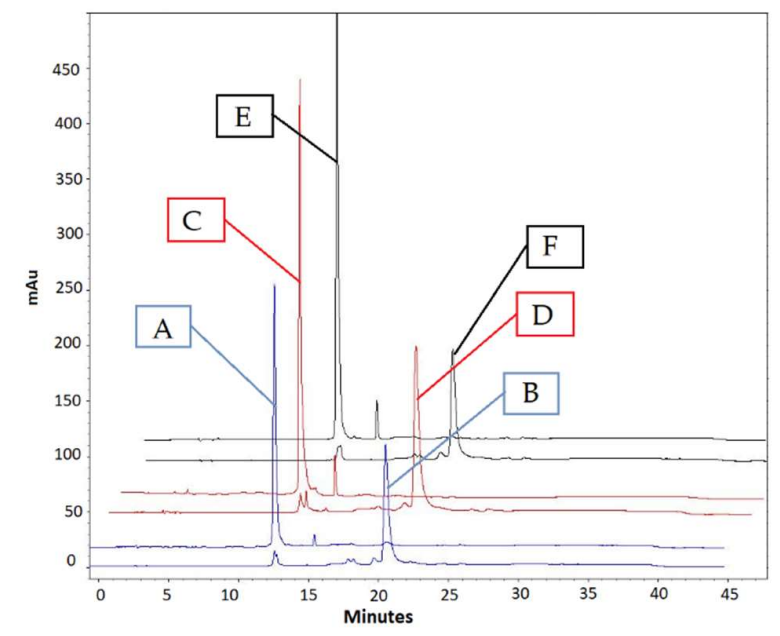

Figure 3. HPLC chromatograms of the free DNAs (A, EUB338; C, NON-EUB338; E, SAU69) and the corresponding DNA-BHHTEGST conjugates (B, EUB338-BHHTEGST; D, NON-EUB338-BHHTEGST; F, SAU69-BHHTEGST) are shown. Chromatograms were obtained using $270 \mathrm{~nm}$ excitation. (Please refer to SI for chromatograms of DNA-BHHTEGST at $270 \mathrm{~nm}$ and $330 \mathrm{~nm}$ ).

The purity of the DNA-BHHTEGST probes played a crucial role for the TGL LISH imaging of $S$. aureus. Unconjugated Europium chelates are small molecules and so tend to bind nonspecifically to the cell membrane and subcellular entities. This creates a highly luminescent unwanted background signal. To counter this, the DNA-BHHTEGS probes were prepared as described to a high purity before their use.

Photophysical properties of DNA-BHHTEGST-Eu ${ }^{3+}$ (DNA = SAU69, EUB338 and NON-EUB338), including UV-visible absorption and luminescence emission spectra, were also investigated. UV-visible absorption analysis of the conjugated oligonucleotides indicated two maximum UV absorbance at $335 \mathrm{~nm}$ (for the Europium chelate) and at $260 \mathrm{~nm}$ (for the DNA), confirming the conjugation of Europium chelate to the oligonucleotides and validating the gel electrophoresis and HPLC data (Figures 2 and 3). The luminescence spectra of conjugated oligonucleotides (DNA-BHHTEGST-Eu ${ }^{3+}$ ) emit luminesce light at $613 \mathrm{~nm}$ when excited at $335 \mathrm{~nm}$ (See Figures S10 and S11).

As shown in Supplementary Figures S10 and S11, for each conjugated DNA, luminescence intensity in milliQ water and Fluorescence Enhancing Buffer [40] (FEB) was measured using a gate delay of $100 \mu \mathrm{s}$ on an Agilent Cary Eclipse fluorescence spectrophotometer. For each compound, luminescent intensity was lowest in water and became enhanced in a FEB solution. The FEB contained Trioctylphosphine 
oxide, where the phosphine oxide group provided a coordination bond to the Europium (III) metal ion and the trioctyl hydrophobic chain repelled the water molecules. This resulted in a reduction of the quenching effect of the water molecule on the Europium (III) metal ions in its excited state and consequently increased the luminescent intensity of the Europium chelate. Because of the increase seen in luminescence output, FEB was added to the stained cells for all the results reported here.

\subsection{LISH Protocol Optimisation and TGL Imaging}

The work flow of homogeneous luminescent in situ hybridisation (LISH) labelling of S. aureus and S. epidermidis (negative control) with DNA-BHHTEGST probe is shown in Figure 4. The SAU69 DNA specific for $S$. aureus with amine modification at $5^{\prime}$ was conjugated quantitatively to the NHS moiety on the TEGylated Europium chelate (BHHTEGST) (Figure 1). S. aureus and S. epidermidis cells were fixed, permeabilised (lysozyme solution) and hybridised to the SAU69 specific DNA-BHHTEGST-Eu ${ }^{3+}$ probe (Figure 4A). The DNA sequence of SAU69 (5'-G AAG CAA GCT TCT CGT CCG) is specific to the ribosomal 16S rRNA of $S$. aureus [34]. The SAU69 probe is not specific to the 16S rRNA sequence of $S$. epidermidis due to three mismatch base pairs [41,42]. These three mismatches were enough to discriminate between S. aureus and S. epidermidis on the basis of their label intensity [42]. The alignments of the SAU69 oligonucleotide probe to its target $16 \mathrm{~S}$ rRNA in S. aureus and its nontarget 16S rRNA in S. epidermidis are shown in Figure 4B,C. This difference made it possible for S. aureus to be selectively hybridised and imaged by TGL microscopy at a high intensity, so that it was easily discriminated from the closely related $S$. epidermidis. High-contrast TGL images were obtained of $S$. aureus with a SNR nearly 8-fold higher than S. epidermidis $\left(\mathrm{SNR}_{\mathrm{S} \text {. aureus }}=35, \mathrm{SNR}_{\mathrm{S} \text {. epidermidis }}=4.6\right)$.

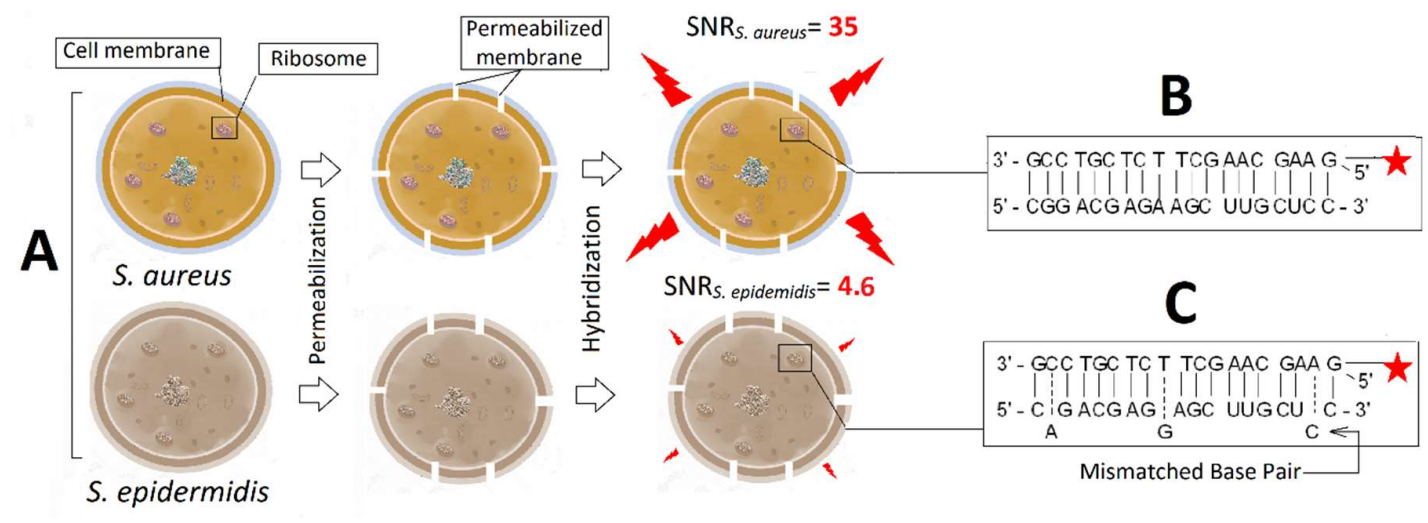

Figure 4. (A) Both S. aureus and S. epidermidis were fixed and permeabilised in parallel and then in situ hybridised with the SAU69-BHHTEGST-Eu ${ }^{3+}$ probe. (B) The 19-mer SAU69 probe aligns with $S$. aureus $16 \mathrm{~S}$ rRNA at the 69 position and (C) has three mismatches to the S. epidermidis rRNA (mismatches are shown in the offset). A SNR of 35 was obtained for the TGL images of S. aureus versus a signal-to-noise ratio (SNR) of 4.6 for S. epidermidis. The Europium (III) ion was added after hybridisation with 4,6-Diamidino-2-phenylindole dihydrochloride hydrate (DAPI) for TGL imaging.

As described in the Experimental section (LISH procedure), the bacterial suspension was fixed before it was permeabilised in situ on the microscope slides. The hybridisation buffer containing the DNA probes solution [DNA-BHHTEGST; DNA-EUB338, NON-EUB338 and SAU69] was added to each well containing these fixed cells and incubated for $2 \mathrm{~h}$. The slides were washed with a wash buffer (WB) to remove any unhybridised DNA probe and the LISH analysis buffer (containing FEB, DAPI and $\mathrm{EuCl}_{3}$ ) was added before visualising the cells with a time-gated microscope.

Optimal hybridisation conditions were determined by (i) varying the hybridisation parameters while analysing the (ii) TGL images of the stained $S$. aureus (acting as the target pathogen) and $S$. epidermidis cells (negative control). The mean intensity of the cell target signal (S) and the mean of the noncell signal $(\mathrm{N})$ was then compared. For hybridisation, the buffer was prepared and tested at various concentrations of formamide (5 to $40 \%$ ) and $\mathrm{NaCl}(0.1$ to $1.0 \mathrm{M})$. According to Poppert et al. [42], 
optimal formamide concentration is dependent on the particular oligonucleotide sequence tested. The $\mathrm{NaCl}$ concentration in the washing buffer depended on the formamide concentration used in the hybridisation buffer.

The hybridisation buffer resulting in the strongest signal was observed to contain $10 \%(w / v)$ formamide, $0.9 \mathrm{M} \mathrm{NaCl}, 20 \mathrm{mM}$ Tris- $\mathrm{HCl} \mathrm{pH}$ 8.0, and 0.01\% sodium dodecyl sulfate (SDS) dissolved in milliQ water. The optimised hybridisation temperature and time were optimised at $70{ }^{\circ} \mathrm{C}$ and $10 \mathrm{~min}$. To minimise nonspecific binding, the samples were then cooled to $46{ }^{\circ} \mathrm{C}$ (over $30 \mathrm{~min}$ ). Next, samples were incubated at $46^{\circ} \mathrm{C}$ for a further $2 \mathrm{~h}$. The washing buffer was optimised at $0.46 \mathrm{M} \mathrm{NaCl}, 20 \mathrm{mM}$ Tris- $\mathrm{HCl} \mathrm{pH} 8.0$, and $0.01 \%$ SDS. The washing buffer was preheated to $46^{\circ} \mathrm{C}$ before incubating it with the samples for $5 \mathrm{~min}$. Slides were flushed with milliQ water, dried with a gentle air blast and then loaded with $2 \mu \mathrm{L}$ of LISH analysis buffer containing the FEB buffer, DAPI and $\mathrm{EuCl}_{3}$. After 15 min incubation, the slides were visualised with the time-gated microscope described above.

\subsection{Differentiation between S. aureus and S. epidermidis}

S. aureus was able to be selectively hybridised and imaged by TGL microscopy at a high intensity, so that it was easily discriminated from the closely-related S. epidermidis. The conjugated DNA (SAU69-BHHTEGST), indicated by the intensity of its signal, bound more to the S. aureus than to the S. epidermidis when prepared and tested in different wells on the same slide. As shown in Figure 5, (A) S. aureus cells were observed to be labelled with much higher signal intensity in comparison with (B) S. epidermidis cells using the SAU69 probe specific for S. aureus. The circles added to indicate the areas selected randomly to quantify the mean-signal-intensity of the desired target cells (S) and the background noise $(\mathrm{N})$.

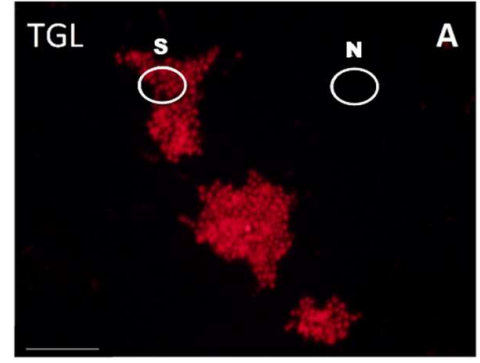

Staphylococcus aureus

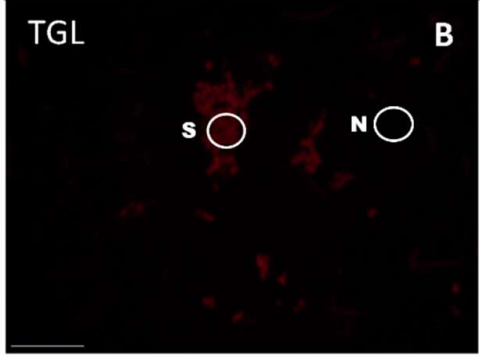

Staphylococcus epidermidis

Figure 5. (A) S. aureus cells labelled with the SAU69-BHHTEGST-Eu ${ }^{3+}$ LISH probe illuminated in the TGL mode are shown. (B) S. epidermidis cells labelled with SAU69-BHHTEGST-Eu ${ }^{3+}$ collected under identical conditions are shown. The scale bar indicates $10 \mu \mathrm{m}$. The circles added indicate the areas selected to calculate the mean signal intensity of the desired target cell $(\mathrm{S})$ and the undesired noise $(\mathrm{N})$.

As shown in Figure 6, in each circle, 10 target cells were selected randomly for the quantification of their signal (S). The SNR of the $S$. aureus (SNR = 31) was nearly 8-fold higher than that of the $S$. epidermidis (SNR = 4.6) images (see Supplementary Figures S12-S17). The EUB338 staining positive control confirmed that the reduced SAU69 signal seen in the S. epidermidis cells was not caused by poor probe penetration, but by the target mismatch of the SAU69 probe.

To support this observation, a commercially available fluorescent probe (SAU69-Alexa Fluor 488, excitation at $488 \mathrm{~nm}$ ) was also used as a positive control for comparison staining of the $S$. aureus cells. The hybridisation was then optimised to maximise fluorescence [21-23] and luminescence yield at the lowest background emission for comparison with the LISH labelling with the SAU69 specific DNA-BHHTEGST-Eu ${ }^{3+}$ probe. After obtaining the corresponding images, the detection sensitivity or SNR of the luminescent Europium probe (SAU69-BHHTEGST-Eu3+) in comparison with fluorescent probe (SAU69-Alexa Fluor 488) for the staining of S. aureus was investigated. ImageJ software was used to quantify the intensity of pixels in the raw images collected of cells stained with both probes. The average SNR calculated for the Europium staining of $S$. aureus cells was 6-fold higher than that 
calculated for the Alexa Fluor 488 stained cells. This confirms that time-gated luminescence (TGL) imaging provides higher sensitivity (SNR) of detection by eliminating the autofluorescence background compared to existing conventional fluorescence probes (Figures S18 and S19).

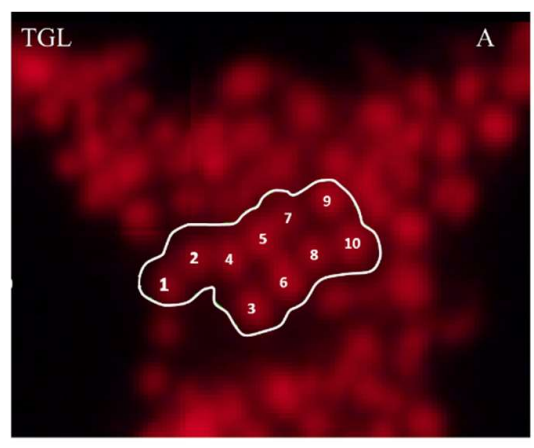

Staphylococcus aureus

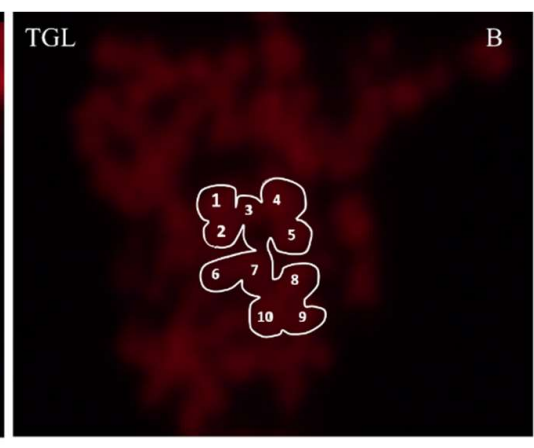

Staphylococcus epidermidis

Figure 6. (A) The circles added indicate the 10 cells of (A) S. aureus and (B) S. epidermidis randomly selected for calculating an average SNR. (A) The mean signal of the 10 cells of $S$. aureus was calculated at $\mathrm{S}=95.7, \mathrm{~N}=3.1$ and $\mathrm{SNR}=31$. (B) S. epidermidis was calculated at $\mathrm{S}=32, \mathrm{~N}=6.9$ and $\mathrm{SNR}=4.6$.

\subsection{Positive/Negative Controls}

The universal eubacteria probe, EUB 338 conjugated to BHHTEGST, was applied to S. aureus and $S$. epidermidis and used as a positive control in these tests. Both S. aureus and S. epidermidis cells were treated identically to those stained with the SAU69 probe using different wells on the same slide. The EUB338 complementary 16S RNA sequence is common to most bacteria [38], and S. aureus and S. epidermidis were stained by the EUB338-BHHTEGST-Eu ${ }^{3+}$ probe almost equally (Figure 7). The stain had a mean pixel value of 72.1 and 81 for $S$. aureus and S. epidermidis cells, respectively (Figures S14 and S15).
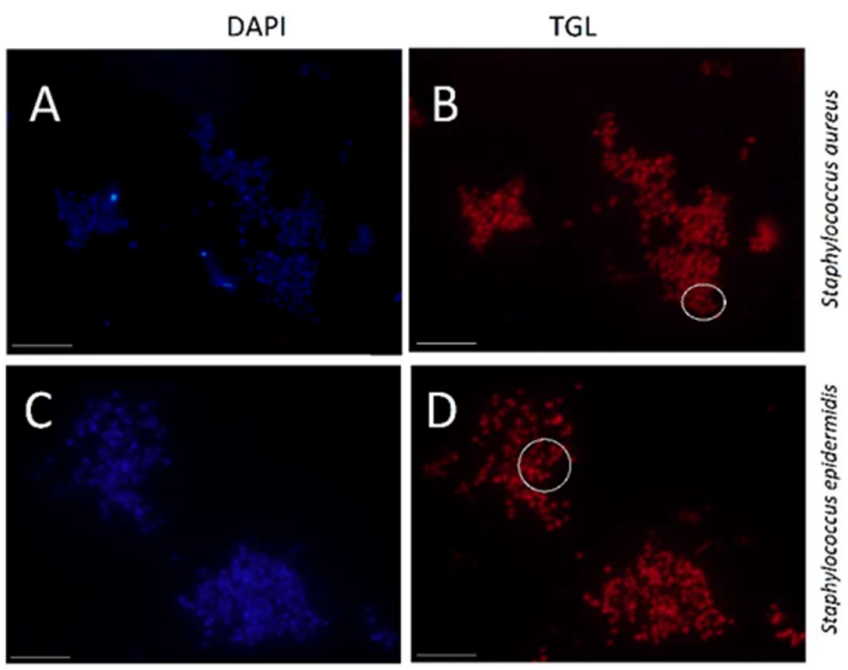

Figure 7. Images of both $S$. aureus $(\mathbf{A}, \mathbf{B})$ and $S$. epidermidis $(\mathbf{C}, \mathbf{D})$ stained with the EUB338-BHHTEGST-Eu ${ }^{3+}$ probe are shown. (A,C) DAPI nuclear staining; (B,D) time-gated luminescence (TGL) staining are shown. Oil immersion 100× objective and TGL exposure times at $2.0 \mathrm{Sec}$. were used. The scale bar indicates $10 \mu \mathrm{m}$. (B) $\mathrm{S}$. aureus is at $\mathrm{S}=72.1, \mathrm{~N}=5$ and $\mathrm{SNR}=14.4$.

(D) S. epidermidis is at $\mathrm{S}=81, \mathrm{~N}=5$ and $\mathrm{SNR}=16.2$.

The NON-EUB338 probe described by Wallner et al. [39] was used as a negative control. Its sequence is absent in most bacterial RNA. The NON-EUB338-BHHTEGST-Eu ${ }^{3+}$ probe had limited staining, with a mean pixel value of 36.7 and 33.8 for S. aureus and S. epidermidis, respectively 
(Figure 8 and Supplementary Figures S16 and S17). These control experiments confirmed that the in situ hybridisation technique was highly specific.
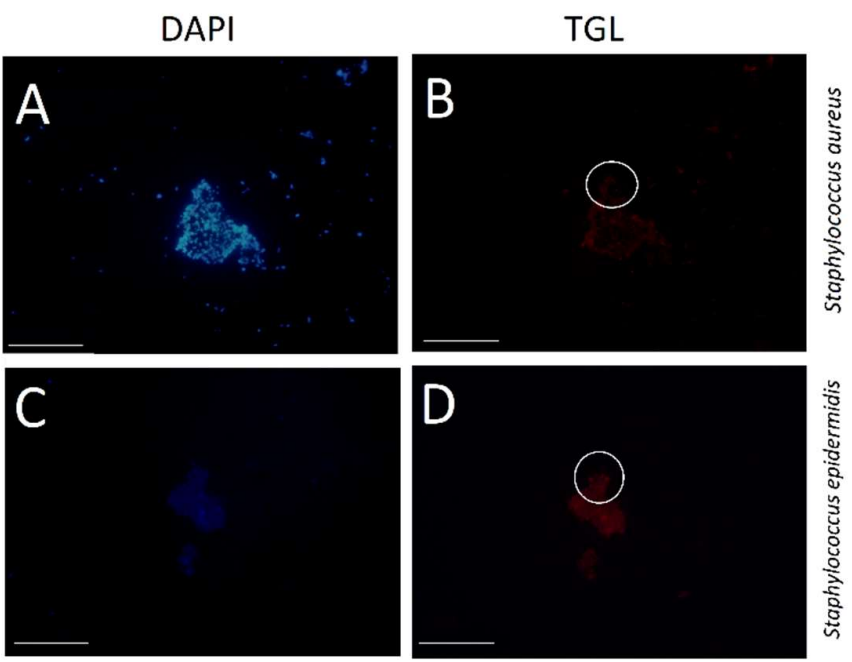

Figure 8. Images of both $S$. aureus $(\mathbf{A}, \mathbf{B})$ and $S$. epidermidis $(\mathbf{C}, \mathbf{D})$ stained with the NON-EUB338-BHHTEGST-Eu ${ }^{3+}$ probe are shown. (A,C) DAPI nuclear staining; (B,D) time-gated luminescence (TGL) are given. Oil immersion 100× objective and TGL exposure times (2.0 Sec.) were used; the scale bar indicates $10 \mu \mathrm{m}$. (B) S. aureus at $\mathrm{S}=36.7, \mathrm{~N}=6.1$ and $\mathrm{SNR}=6$ and (D) S. epidermidis at $\mathrm{S}=33.8, \mathrm{~N}=7.3$ and $\mathrm{SNR}=4.6$.

Figure 9 shows the averaged results $(n=30)$ of luminescent stained S. aureus and S. epidermidis visualised by LISH. The mean signal intensity for S. aureus was 3.5 times higher than that for S. epidermidis for the SAU69-BHHTEGST-Eu ${ }^{3+}$ probe. Further, for the same probe (SAU69-BHHTEGST-Eu ${ }^{3+}$ ), the mean signal-to-noise ratio (SNR) of $S$. aureus was 8 times higher than that for S. epidermidis (Supplementary Figures S12 and S13, Table S2).

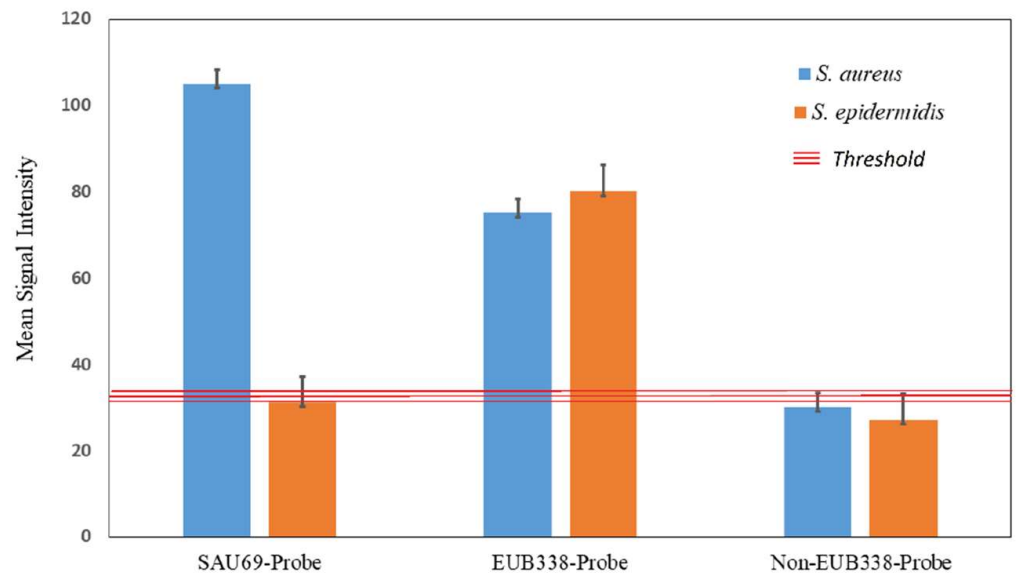

Figure 9. The $S$. aureus and $S$. epidermidis labelled with SAU69-BHHTEGST-Eu ${ }^{3+}$, EUB338-BHHTEGST-Eu ${ }^{3+}$ and NON-EUB338-BHHTEGST-Eu ${ }^{3+}$, the threshold of the luminescence intensity and standard deviation $(\mathrm{SDV})$ are shown as a mean $(\mathrm{n}$ replication $=30)$ signal intensity (See SI Table S2).

The EUB338-BHHTEGST-Eu ${ }^{3+}$ (positive control) probe labelled both S. aureus and S. epidermidis with a similar intensity. Luminescent intensity of the images in the negative controls (NON-EUB338) was negligible, which suggests the presence of some minor nonspecific binding of probes within the cells. However, the mean luminescent intensity of the images with the positive probes (SAU69 and 
EUB338) was consistently much higher than the threshold of the negative controls (NON-EUB338), as depicted in Figure 9. Specifically, labelled S. aureus (SAU69-BHHTEGST-Eu ${ }^{3+}$ ) was 3.2 times brighter than the same cells labelled with the NON-EUB338-BHHTEGST-Eu ${ }^{3+}$ probe (negative control).

It is a common approach to classify the fluorescence in situ hybridisation (FISH) images into target (positive) cells and nontarget (negative) cells based on a threshold of the fluorescence intensity or signal-to-noise ratio (SNR) [43-47]. It means all cells with higher fluorescence intensity than a certain threshold are classified as target cells. Those cells with a signal less than this threshold were classified as nontarget cells. For example, Pernthaler et al. [44] developed automated digital microscopy to facilitate the processing of a large number of FISH-stained samples based on a threshold level classification that was determined on samples hybridised with the NON-EUB338 probe as negative control. The positive FISH-stained targets were classified based upon their higher signal intensity or higher signal-to-noise ratio relative to the threshold of the signal from the negative control.

This simple threshold-based classification approach used with our data was confirmed with the mean luminescent signal intensity of the positive control probes observed to be consistently higher than the threshold of the mean signal from the negative probes. Specifically, both EUB338 labelled $S$. aureus and $S$. epidermidis showed the same mean signal intensity of $\sim 3.2$ times higher signal intensity than the threshold of signal from the negative control (NON-EUB338). Using this negative control threshold of NON-EUB338 probe staining (as shown in Figure 9), the SAU69-BHHTEGST-Eu ${ }^{3+}$ probe $^{-}$ specifically stained $S$. aureus with a mean signal intensity of 3.5 times higher than the threshold level of signal from S. epidermidis.

\section{Conclusions}

In summary, homogeneous luminescent in situ hybridisation (LISH) assays with time-gated microscopy provide inexpensive, sensitive and rapid identification of pathogenic bacteria. Homogeneous fluorescent in situ hybridisation (FISH) has been extensively used for a wide range of applications in comparison with other molecular methods such as PCR, nanoparticle DNA-based biosensor and DNA microarray approaches, which have their own specific and limited applications. This report provides a proof-of-principle for LISH detection of S. aureus with high specificity and sensitivity (SNR) and its differentiation from a close relative S. epidermidis. LISH compared to FISH has the advantage of eliminating the background autofluorescence, which is a major limitation of conventional fluorescence microscopic assays. LISH compared to the conventional blood test detection method can be performed at an at least 10-fold less cost in term of time taken.

The direct conjugation of a single Europium chelate to a DNA probe provides ease and improvement over existing BSA/streptavidin/biotinylated DNA, and more importantly, the smaller size of the conjugate facilitates hybridisation through permeabilised bacterial cell membrane to target intracellular rRNA. We believe the current study provides an effective alternate sensitive protocol for the detection of intracellular DNA/RNA targets by luminescent in situ hybridisation.

\section{Experimental Section}

\subsection{Materials}

4,6-Diamidino-2-phenylindole dihydrochloride hydrate (DAPI) (D9642), Europium (III) chloride hexahydrate (203254), paraformaldehyde (P6148), sodium tetraborate decahydrate (1303-96-4), sodium acetate (S3272), lyophilised powder (lysozyme from chicken egg white; L6876), tris(hydroxymethyl)aminomethane (tris base -252859), boric acid (B6768), ethylenediaminetetraacetic acid (EDTA, E9884), formamide (47670), sodium dodecyl sulfate (SDS, L3771), N,N-dimethylformamide (DMF, 227056), dimethyl sulfoxide (DMSO, 472301), tetramethylethylenediamine (TEMED-T7024), sodium persulfate (216232), 30\% acrylamide (contains 1\% methylene bis acrylamide) (A3574), urea (U5378) and agarose (A0169) were purchased from Sigma-Aldrich, Australia and used without further modification. DNA oligonucleotides modified at their $5^{\prime}$-end with an amino group, including the 
sequences EUB338 (nonselective probe), NON-EUB338 (negative control probe) and SAU69 specific for S. aureus, were purchased from Integrated DNA Technologies Australia. S. aureus and S. epidermidis cells (from patient samples that were first identified via blood-culturing and PCR) were provided by Westmead Hospital, Sydney, Australia with permission. Teflon coated microscope slides (G401-12) containing wells $(7 \times 3)$ were purchased from ProSciTech, Australia.

\subsection{The Conjugation of Europium Chelate to DNA}

BHHTEGST, utilising a succinimide reactive group, was covalently attached to a modified DNA containing a primary amino group at its $5^{\prime}$-residue using $\mathrm{NaHCO}_{3}$ buffer $(100 \mathrm{mM}, \mathrm{pH}$ of 8.5$)$ for incubation for $1 \mathrm{hr}$ at $37^{\circ} \mathrm{C}$. Purification was carried out using a common ethanol precipitation procedure. A total of $100 \mu \mathrm{L}$ of milliQ water solution containing DNA (SAU69 [5'-amino-G AAG CAA GCT TCT CGT CCG] $1086.4 \mu \mathrm{g}, 176.7 \mathrm{nmol}$ ) was prepared as a stock solution. Then, $10 \mu \mathrm{L}$ aliquot of this was purified by precipitation by adding sodium acetate solution $(2 \mu \mathrm{L}, \mathrm{pH} 5.5,3 \mathrm{M})$ and ethanol $(400 \mu \mathrm{L})$. The mixture was vortexed and kept at $-80^{\circ} \mathrm{C}$ for $15 \mathrm{~min}$. The precipitated DNA was then collected by centrifuging for $2 \mathrm{~min}$ at $16 \mathrm{~K} \mathrm{rpm}$. The precipitated DNA was dissolved in $10 \mu \mathrm{L}$ of milliQ water. This procedure was repeated twice more to obtain pure DNA.

Pure DNA was dissolved in $10 \mu \mathrm{L}$ of milliQ water. A total of $10 \mu \mathrm{L}$ of sodium tetraborate $(0.2 \mathrm{M}$, pH 8.5) was added. This was followed by the addition of $20 \mu \mathrm{L}$ of BHHTEGST solution $(10 \mathrm{mg}$ in $500 \mu \mathrm{L}$ of DMSO, $20 \mathrm{mM}$ to form molar excess of BHHTEGST to DNA of 20). The mixture was incubated for one hour at room temperature to complete the conjugation of BHHTEGST to DNA. Excess BHHTEGST was removed from the formed conjugated oligonucleotide probe by its precipitation in ethanol. A total of $2 \mu \mathrm{L}$ of sodium acetate solution $(\mathrm{pH} 5.5,3 \mathrm{M})$ and $400 \mu \mathrm{L}$ of ethanol was added to this reaction mixture. The precipitates were collected by first cooling to $-80{ }^{\circ} \mathrm{C}$, then centrifuged again at $16 \mathrm{~K} \mathrm{rpm}$ for $15 \mathrm{~min}$. The procedure was repeated 3 times to obtain the crude probe extract SAU69-BHHTEGST. The same procedure was used to prepare the other DNA conjugates of EUB338-BHHTEGST and NON-EUB338-BHHTEGST. The purity of these conjugates was measured using gel electrophoresis and analytical HPLC techniques. The results are shown in Figures 2 and 3 and in the SI. The DNA sequences used for in the conjugation are listed next:

EUB338: 5'-G CTG CCT CCC GTA GGA GT (acting as a nonselective probe);

NON-EUB338: 5'-C GAC GGA GGG CAT CCT CA (acting as a negative control probe);

SAU69: 5'-G AAG CAA GCT TCT CGT CCG (acting as a probe specific for S. aureus).

\subsection{Electrophoresis Solution and Gel Preparation}

Gel electrophoresis conductive medium 1X TBE solution was prepared by diluting 5X TBE solution (54 g Tris, $27.5 \mathrm{~g}$ boric acid and $500 \mathrm{mg}$ EDTA) in $1 \mathrm{~L}$ of milliQ water. The gel was prepared with $20 \mathrm{~mL}$ of $30 \%$ acrylamide (containing 1\% (w/v) methylene bis acrylamide), $12 \mathrm{~g}$ urea and $6 \mathrm{~mL} 5 \mathrm{X}$ TBE to $30 \mathrm{~mL}$ of milliQ water. Seven millilitres of this mixture was added to $30 \mu \mathrm{L}$ of $10 \%$ sodium persulfate (at a concentration of $30 \mathrm{mg}$ in $300 \mu \mathrm{L}$ of milliQ water) and $3 \mu \mathrm{L}$ of tetramethylethylenediamine (TEMED). This solution was quickly injected between two layers of glass. It was then held for $10 \mathrm{~min}$ until a gel formed.

\subsection{Gel Imaging}

After completion of the gel electrophoresis, both free and conjugated DNA with the Europium ligand were visualised by exciting with a UV-visible set at $254 \mathrm{~nm}$. Crude precipitated DNA-BHHTEGST, after its conjugation and precipitation in ethanol, was dissolved in $10 \mu \mathrm{L}$ of milliQ water, and $1 \mu \mathrm{L}$ was then mixed with $5 \mu \mathrm{L}$ of a marker (bromophenol blue (BPB) dissolved in $1 \mathrm{X}$ TBE) and applied to the electrophoresis pocket. After completing the gel electrophoresis, the gel was illuminated with a $260 \mathrm{~nm}$ UV lamp to identify the DNA and DNA probe. A few drops of $\mathrm{EuCl}_{3}$ solution $(3 \mathrm{mM})$ were added to the gel, and the conjugated DNA-Europium chelate (DNA-BHHTEGST-Eu ${ }^{3+}$ ) was visualised under 
UV-visible light set to $365 \mathrm{~nm}$. At this wavelength, only the DNA Europium conjugates were seen. The Europium moiety of DNA probe was excited by and emitted a red colour (613 nm) (Figure. 2).

\subsection{Analytical HPLC Analysis of DNA Conjugates}

For the analysis of DNA and conjugated DNA with Europium chelate, analytical reversed phase HPLC, DENALI C18 column ( $5 \mu \mathrm{m}, 4.6 \mathrm{~mm}$ ID, $250 \mathrm{~mm}$ ) at a flow rate of $1.0 \mathrm{~mL} / \mathrm{min}$, was used. A Shimadzu LC system consisting of a DGV-12A degasser, SIL-10AD auto-injector, and an SPD-M10A tuneable absorbance detector was coupled to the HPLC. Solvent system of solvent A (0.1 M triethylammonium acetate at $\mathrm{pH} 6.5)$ and solvent $\mathrm{B}(0.1 \mathrm{M}$ triethylammonium acetate in $75 \%$ acetonitrile, $\mathrm{pH}$ 6.5) was applied at 10 to $100 \%$ B gradient concentrations over a 20 -min period.

\subsection{Photophysical Properties of DNA Conjugates}

Photophysical properties of DNA-BHHTEGST-Eu ${ }^{3+}$ (DNA = SAU69, EUB338 and NON-EUB338), including UV-visible absorption spectra, were collected using a NanoDrop 2000 UV (Thermo Scientific) spectrometer. Luminescence data were captured with an Agilent Cary Eclipse Fluorescence Spectrophotometer. See SI for more details (Figures S10 and S11).

\subsection{The Cells (S. aureus and S. epidermidis)}

Blood agar plates of clinical isolates positive for S. aureus or S. epidermidis were collected from Westmead hospital (University Biosafety Committee approvals 09/14/LAB and 5201000927) after each isolate's identity was confirmed using their own in-house polymerase chain reaction (PCR) technique [48]. Cells were prepared for testing by first growing to log phase, isolation by centrifugation and then their re-suspension in ethanol. This treatment made the cells viable and helped to fix their cellular architecture. Treated this way, they could be stored long-term and could be handled safely when tested.

\subsection{Buffers}

Hybridisation buffer (HB) was prepared with $\mathrm{NaCl}(360 \mu \mathrm{L}, 5 \mathrm{M})$ and Tris/ $\mathrm{HCl}(40 \mu \mathrm{L}, \mathrm{pH}$ 8.0, $1 \mathrm{M})$, formamide $(200 \mu \mathrm{L})$, milliQ water $(1.40 \mathrm{~mL})$ and SDS $(10 \%(\mathrm{w} / \mathrm{v}), 2 \mu \mathrm{L})$ and then made to form a volume of $2 \mathrm{~mL}$. Washing buffer (WB) was prepared with $\mathrm{NaCl}(4.60 \mathrm{~mL}, 5 \mathrm{M})$, Tris/ $\mathrm{HCl}(1 \mathrm{~mL} \mathrm{pH} \mathrm{8.0,}$ $1 \mathrm{M})$, SDS $(10 \%, 50 \mu \mathrm{L})$ and milliQ water $(48.49 \mathrm{~mL})$ and made up to a volume of $50 \mathrm{~mL}$. LISH analysis buffer (LAB) was prepared by mixing fluorescence enhancement buffer (FEB) [40] (1 mL, 1 X, $5 \mu \mathrm{L}$ of DAPI solution $(1.0 \mu \mathrm{g} / \mathrm{mL})$ and a Europium (III) chloride solution $(10 \mu \mathrm{L}$ of $3 \mathrm{mM})$.

Preparation of fluorescence enhancing buffer solution [10 $(\mathrm{FEB})]$ was done in accordance with Arnaud et al. [40]. A $44 \mathrm{~mL}$ solution of $0.1 \mathrm{M}$ sodium hydroxide was prepared, and the $\mathrm{pH}$ was adjusted to 4.7 with glacial acetic acid, then $1 \%$ by volume of Triton X-100 was added. Trioctylphosphine oxide $(38 \mathrm{mg})$ was dissolved in ethanol $(5 \mathrm{~mL})$ and added to the sodium acetate solution $(1.25 \mathrm{~mL})$, and then $1 \times$ FEB was used for the experiments.

Lysozyme solution was prepared by dissolving lysozyme $(15 \mathrm{mg})$ in $0.1 \mathrm{M} \mathrm{Tris} / \mathrm{HCl} \mathrm{pH} 8.0(1 \mathrm{~mL})$ just before its use. A laboratory-built hybridisation oven, equipped with a sealed chamber, was used for all incubations. It could hold 3 regular slides at once. It maintained an atmospheric humidity of $100 \%$. Its temperature was maintained at $\pm 0.5^{\circ} \mathrm{C}$.

\subsection{LISH Procedure}

A dilute solution of agarose $(0.02 \% w / v)$ was prepared in milliQ water. A total of $20 \mu \mathrm{L}$ of this solution was then pipetted onto wells in a $7 \times 3$ Teflon well coated slide (ProSciTech G401-12). The addition of agarose to the slides aided sample adhesion and appeared to improve fluorescent emission intensity. Each prepared slide was placed on a hot plate and dried at $80^{\circ} \mathrm{C}$ for $10 \mathrm{~min}$. The slides were then cooled to RT, and a bacterial suspension $(10 \mu \mathrm{L})$ was added to each well at a 
concentration of around $1 \times 10^{6}$ cells $/ \mathrm{mL}$. It was then dried briefly for a few minutes using a hot plate set to $30^{\circ} \mathrm{C}$. It is important for the slides not to be heated for too long or be overheated. Doing so causes damage to the cells. To ensure control over positive and negative labelling, the first row in each slide was loaded with $S$. aureus and the second with $S$. epidermidis.

For permeabilisation, $20 \mu \mathrm{L}$ of lysozyme solution was added to each well. Slides were then incubated in $100 \%$ humid chamber at $37^{\circ} \mathrm{C}$ for $1 \mathrm{~h}$. Subsequently, slides were removed and gently washed with $3 \times 100 \mu \mathrm{L}$ aliquots of $95 \%$ ethanol.

From the probe stock solution [SAU69-BHHTEGST $(100 \mu \mathrm{L}, 1.4 \mathrm{mM})$ ], $1 \mu \mathrm{L}$ was added to $100 \mu \mathrm{L}$ hybridisation buffer [14.1 pM probe/ $\mu \mathrm{L}$ of hybridisation buffer $(\mathrm{HB})]$, and then $10 \mu \mathrm{L}$ of this was added to each well. The hybridisation oven was preheated to $70{ }^{\circ} \mathrm{C}$. After adding $10 \mu \mathrm{L}$ hybridisation buffer (HB) (with probe) to each well, the slides were loaded into the oven set to $100 \%$ atmospheric humidity. The slides were left at $70{ }^{\circ} \mathrm{C}$ for $10 \mathrm{~min}$ before cooling slowly to $46^{\circ} \mathrm{C}$, over a 30 -min period. They were then held for another $2 \mathrm{~h}$ at $46^{\circ} \mathrm{C}$. After this, the slides were removed and each well washed with washing buffer (WB) $2 \times 100 \mu \mathrm{L}$ gently. Subsequently, they were immersed in $40 \mathrm{~mL}$ of pre-heated $46{ }^{\circ} \mathrm{C}$ wash buffer (WB) for $5 \mathrm{~min}$.

After washing, the slides were flushed with milliQ water and dried using a gentle air blast. The wells were then loaded with $2 \mu \mathrm{L}$ of LISH analysis buffer [FEB buffer $(1 \mathrm{~mL}, 1 \mathrm{X}), 5 \mu \mathrm{L}$ of DAPI solution $(1.0 \mu \mathrm{g} / \mathrm{mL})$ and the Europium chloride solution $(10 \mu \mathrm{L}$ of $3 \mathrm{mM})]$. They were covered with a long-length glass cover-slip. After leaving the slides on the bench for $15 \mathrm{~min}$ to incubate, they were visualised with the time-gated microscope system described next.

\subsection{Imaging}

The fixed and permeabilised S. aureus and S. epidermidis cells were hybridised and treated with LISH analysis buffer (described in the LISH procedure section of this work), and the thus labelled cells were then visualised using an Olympus CKX41 inverted microscope. $\mathrm{EuCl}_{3}$ solution was added with LISH analysis buffer after completing the labelling procedure to reduce nonspecific binding and aggregation of the DNA-probe.

Bright-field, DAPI and time-gated luminescence (TGL) images were then captured with the Olympus CKX41 fluorescence microscope. Time-gated luminescence images were captured with the gated autosynchronous luminescence detector (GALD) system developed by Connally [37]. This was used by first inserting the unit into the differential interference contrast (DIC) slot on the microscope. For TGL Images, a DP72 colour camera set at an ASA speed of 400 and an exposure period of $2.0 \mathrm{~s}$ were used. Images were stored as TIFF files using the same UV lamp source and a DAPI filter, after an exposure of $10 \mathrm{~ms}$ DAPI. The images acquired were not further processed, enhanced or manipulated.

The images of the $S$. aureus and $S$. epidermidis cells using the time-gated mode were captured with a DP72 Olympus camera. It was set at 400 ASA and an exposure of $2.0 \mathrm{~s}$. Images were analysed with ImageJ software to calculate their signal-to-noise ratio (SNR). Images were acquired as a 24-bit (RGB) TIFF format image. The red histogram channel carried the image's brightness information. The maximum brightness of an 8-bit pixel corresponded to a 255 value.

\subsection{Quantification of Signal-to-Noise Ratio (SNR)}

The mean signal intensity and signal-to-noise (SNR) of the stained cell images were quantified using ImageJ software (version 1.46r). ImageJ calculated the mean signal intensity (S) of an area within the target cell, and the noise (N) was calculated by comparing it to the mean pixel intensity of a randomly selected area containing no cells.

Supplementary Materials: The Supporting Information is available on the Molecules Publications website at DOI: xxx. Analytical HPLC profile of the DNA conjugates and the quantification details of their signal-to-noise ratio (SNR) is provided here as well. 
Author Contributions: N.S., R.C., T.S.L., J.Y., N.H.P. and J.A.P. conceived the study. N.S., R.C. and T.S.L. performed the experimental lab work and imaging. N.S. composed the manuscript and prepared all figures. All authors reviewed the manuscript.

Funding: Thanks to the Paige Weatherspoon Foundation, the Macquarie University IP Development Funding Grant Acc No. 9201002101 and ARC Centre of Excellence for Nanoscale BioPhotonics (Grant CE140100003) for their financial support. Thanks to Westmead hospital for providing S. aureus and S. epidermidis samples.

Acknowledgments: Special thanks to Arkady Mustaev (PHRI Centre, New Jersey Medical School; 225 Warren Street, Newark, New Jersey; 07103 USA) for invaluable advice on the efficient purification of the conjugated DNA Europium chelator and Liisa Kautto for her insightful suggestions.

Conflicts of Interest: The authors declare no conflict of interest. The authors declare no competing financial interest.

Data Availability: The images and datasets generated and analysed during the current study are available from the corresponding author on reasonable request.

\section{References}

1. Gómez-Pavón, J.; Rodríguez, J.S.; de la Puente Fernández, E.; Baztán, J.C.; Ruipérez, I.C.; González, I.; Cortés, R.B. Staphylococcus aureus infection in an acute geriatric unit. Rev. Esp. De Geriatr. Y Gerontol. 2010, 45, 5-9. [CrossRef] [PubMed]

2. Reighard, A.; Diekema, D.; Wibbenmeyer, L.; Ward, M.; Herwaldt, L. Staphylococcus aureus nasal colonization and colonization or infection at other body sites in patients on a burn trauma unit. Infect. Control Hosp. Epidemiol. 2009, 30, 721-726. [CrossRef] [PubMed]

3. Liu, C.; Bayer, A.; Cosgrove, S.E.; Daum, R.S.; Fridkin, S.K.; Gorwitz, R.J.; Kaplan, S.L.; Karchmer, A.W.; Levine, D.P.; Murray, B.E. Clinical practice guidelines by the infectious diseases society of america for the treatment of methicillin-resistant staphylococcus aureus infections in adults and children. Clin. Infect. Dis. 2011, 52, e18-e55. [CrossRef] [PubMed]

4. Yamamoto, Y. Pcr in diagnosis of infection: Detection of bacteria in cerebrospinal fluids. Clin. Diagn. Lab. Immunol. 2002, 9, 508-514. [CrossRef] [PubMed]

5. Ellerbrok, H.; Nattermann, H.; Özel, M.; Beutin, L.; Appel, B.; Pauli, G. Rapid and sensitive identification of pathogenic and apathogenic bacillus anthracis by real-time pcr. FEMS Microbiol. Lett. 2002, 214, 51-59. [CrossRef] [PubMed]

6. Ratnayake, L.; Olver, W.J. Rapid pcr detection of methicillin-resistant staphylococcus aureus and methicillin-sensitive s. Aureus samples from charcoal-containing blood culture bottles. J. Clin. Microbiol. 2011, 49, 2382. [CrossRef]

7. Cao, X.; Ye, Y.; Liu, S. Gold nanoparticle-based signal amplification for biosensing. Anal. Biochem. 2011, 417, 1-16. [CrossRef]

8. Torres-Chavolla, E.; Alocilja, E.C. Nanoparticle based DNA biosensor for tuberculosis detection using thermophilic helicase-dependent isothermal amplification. Biosens. Bioelectron. 2011, 26, 4614-4618. [CrossRef]

9. Chen, S.-H.; Wu, V.C.; Chuang, Y.-C.; Lin, C.-S. Using oligonucleotide-functionalized au nanoparticles to rapidly detect foodborne pathogens on a piezoelectric biosensor. J. Microbiol. Methods 2008, 73, 7-17. [CrossRef] [PubMed]

10. Sun, Y.; He, X.; Ji, J.; Jia, M.; Wang, Z.; Sun, X. A highly selective and sensitive electrochemical cs-mwcnts/au-nps composite DNA biosensor for staphylococcus aureus gene sequence detection. Talanta 2015, 141, 300-306. [CrossRef] [PubMed]

11. Vautor, E.; Magnone, V.; Rios, G.; Le Brigand, K.; Bergonier, D.; Lina, G.; Meugnier, H.; Barbry, P.; Thiery, R.; Pepin, M. Genetic differences among staphylococcus aureus isolates from dairy ruminant species: A single-dye DNA microarray approach. Vet. Microbiol. 2009, 133, 105-114. [CrossRef] [PubMed]

12. Ruan, M.; Niu, C.-G.; Zeng, G.-M.; Qin, P.-Z.; Wang, X.-Y.; Huang, D.-W.; Huang, J.; Fan, C.-Z. Rapid detection of staphylococcus aureus via a sensitive DNA hybridization assay based on a long-lifetime luminescent europium marker. Microchim. ACTA 2011, 175, 105. [CrossRef]

13. Xia, H.; Wang, F.; Huang, Q.; Huang, J.; Chen, M.; Wang, J.; Yao, C.; Chen, Q.; Cai, G.; Fu, W. Detection of staphylococcus epidermidis by a quartz crystal microbalance nucleic acid biosensor array using au nanoparticle signal amplification. Sensors 2008, 8, 6453-6470. [CrossRef] [PubMed] 
14. Zhang, D.; Yan, Y.; Li, Q.; Yu, T.; Cheng, W.; Wang, L.; Ju, H.; Ding, S. Label-free and high-sensitive detection of salmonella using a surface plasmon resonance DNA-based biosensor. J. Biotechnol. 2012, 160, 123-128. [CrossRef]

15. Qin, P.-Z.; Niu, C.-G.; Ruan, M.; Zeng, G.-M.; Wang, X.-Y. A novel bifunctional europium complex as a potential fluorescent label for DNA detection. Analyst 2010, 135, 2144-2149. [CrossRef] [PubMed]

16. Wu, Q.; Li, Y.; Hu, H.; Wang, M.; Wu, Z.; Xu, W. Rapid identification of staphylococcus aureus: Fish versus pcr methods. Lab. Med. 2012, 43, 276-280. [CrossRef]

17. Tavares, A.; Inácio, J.; Melo-Cristino, J.; Couto, I. Use of fluorescence in situ hybridization for rapid identification of staphylococci in blood culture samples collected in a portuguese hospital. J. Clin. Microbiol. 2008, 46, 3097-3100. [CrossRef]

18. Hartmann, H.; Stender, H.; Schäfer, A.; Autenrieth, I.B.; Kempf, V.A. Rapid identification of staphylococcus aureus in blood cultures by a combination of fluorescence in situ hybridization using peptide nucleic acid probes and flow cytometry. J. Clin. Microbiol. 2005, 43, 4855-4857. [CrossRef]

19. Shrestha, N.K.; Scalera, N.M.; Wilson, D.A.; Brehm-Stecher, B.; Procop, G.W. Rapid identification of staphylococcus aureus and methicillin resistance by flow cytometry using a peptide nucleic acid probe. J. Clin. Microbiol. 2011, 49, 3383-3385. [CrossRef] [PubMed]

20. Frickmann, H.; Zautner, A.E.; Moter, A.; Kikhney, J.; Hagen, R.M.; Stender, H.; Poppert, S. Fluorescence in situ hybridization (fish) in the microbiological diagnostic routine laboratory: A review. Crit. Rev. Microbiol. 2017, 43, 263-293. [CrossRef]

21. Lawson, T.; Connally, R.; Vemulpad, S.; Piper, J. Dimethyl formamide-free, urea-nacl fluorescence in situ hybridization assay for staphylococcus aureus. Lett. Appl. Microbiol. 2012, 54, 263-266. [CrossRef]

22. Lawson, T.S.; Connally, R.E.; Iredell, J.R.; Vemulpad, S.; Piper, J.A. Detection of staphylococcus aureus with a fluorescence in situ hybridization that does not require lysostaphin. J. Clin. Lab. Anal. 2011, 25, 142-147. [CrossRef]

23. Lawson, T.S.; Connally, R.E.; Vemulpad, S.; Piper, J.A. Optimization of a two-step permeabilization fluorescence in situ hybridization (fish) assay for the detection of staphylococcus aureus. J. Clin. Lab. Anal. 2011, 25, 359-365. [CrossRef]

24. Lakowicz, J.R. Principles of Fluorescence Spectroscopy, 2nd ed.; Plenum Press: New York, NY, USA, 1999 ; p. 496.

25. Selvin, P.R. Principles and biophysical applications of lanthanide-based probes. Annu. Rev. Biophys. Biomol. Struct. 2002, 31, 275. [CrossRef]

26. Yuan, J.; Matsumoto, K.; Kimura, H. A new tetradentate $\beta$-diketonate- europium chelate that can be covalently bound to proteins for time-resolved fluoroimmunoassay. Anal. Chem. 1998, 70, 596-601. [CrossRef] [PubMed]

27. Connally, R.E.; Piper, J.A. Time-gated luminescence microscopy. Ann. N. Y. Acad. Sci. 2008, 1130, 106-116. [CrossRef]

28. Connally, R.; Veal, D.; Piper, J. Time-resolved fluorescence microscopy using an improved europium chelate bhhst for the in situ detection of cryptosporidium and giardia. Microsc. Res. Tech. 2004, 64, 312-322. [CrossRef]

29. Sayyadi, N.; Connally, R.E.; Try, A. A novel biocompatible europium ligand for sensitive time-gated immunodetection. Chem. Commun. 2016, 52, 1154-1157. [CrossRef]

30. Sayyadi, N.; Care, A.; Connally, R.E.; Try, A.C.; Bergquist, P.L.; Sunna, A. A novel universal detection agent for time-gated luminescence bioimaging. Sci. Rep. 2016, 6. [CrossRef]

31. Sayyadi, N.; Justiniano, I.; Connally, R.E.; Zhang, R.; Shi, B.; Kautto, L.; Everest-Dass, A.V.; Yuan, J.; Walsh, B.J.; Jin, D.; et al. Sensitive time-gated immunoluminescence detection of prostate cancer cells using a tegylated europium ligand. Anal. Chem. 2016, 88, 9564-9571. [CrossRef]

32. Sueda, S.; Yuan, J.; Matsumoto, K. Homogeneous DNA hybridization assay by using europium luminescence energy transfer. Bioconjugate. Chem. 2000, 11, 827-831. [CrossRef]

33. Yoshikawa, K.; Yuan, J.; Matsumoto, K.; KIMURA, H. Time-resolved fluorometric detection of DNA using a tetradentate $\beta$-diketonate europium chelate as a label. Anal. Sci. 1999, 15, 121-124. [CrossRef]

34. Kempf, V.A.; Trebesius, K.; Autenrieth, I.B. Fluorescent in situ hybridization allows rapid identification of microorganisms in blood cultures. J. Clin. Microbiol. 2000, 38, 830-838. 
35. Connally, R.; Piper, J. Solid-state time-gated luminescence microscope with ultraviolet light-emitting diode excitation and electron-multiplying charge-coupled device detection. J. Biomed. Opt. 2008, 13, 34022-34026. [CrossRef]

36. Jin, D.; Piper, J.A. Time-gated luminescence microscopy allowing direct visual inspection of lanthanide-stained microorganisms in background-free condition. Anal. Chem. 2011, 83, 2294-2300. [CrossRef]

37. Connally, R. A device for gated autosynchronous luminescence detection. Anal. Chem. 2011, 83, 4782-4787. [CrossRef]

38. Amann, R.I.; Binder, B.J.; Olson, R.J.; Chisholm, S.W.; Devereux, R.; Stahl, D.A. Combination of 16s rrna-targeted oligonucleotide probes with flow cytometry for analyzing mixed microbial populations. Appl. Environ. Microbiol. 1990, 56, 1919-1925.

39. Wallner, G.; Amann, R.; Beisker, W. Optimizing fluorescent in situ hybridization with rrna-targeted oligonucleotide probes for flow cytometric identification of microorganisms. Cytom. Part A 1993, 14, 136-143. [CrossRef]

40. Arnaud, N.; Georges, J. Fluorimetric determination of europium over a large dynamic range using its ternary complex with thenoyltrifluoroacetone and trioctylphosphine oxide in a micellar solution of triton x-100. Analyst 1997, 122, 143-146. [CrossRef]

41. Lawson, T.S.; Connally, R.E.; Vemulpad, S.; Piper, J.A. In silico evaluation and testing of fluorescence in situ hybridization 16s rrna probes for staphylococcus aureus. Lab. Med. 2015, 42, 729-734. [CrossRef]

42. Poppert, S.; Riecker, M.; Wellinghausen, N.; Frickmann, H.; Essig, A. Accelerated identification of staphylococcus aureus from blood cultures by a modified fluorescence in situ hybridization procedure. $J$. Med. Microbiol. 2010, 59, 65-68. [CrossRef]

43. Li, S.; Spear, R.N.; Andrews, J.H. Quantitative fluorescence in situ hybridization of aureobasidium pullulans on microscope slides and leaf surfaces. Appl. Env. Microbiol. 1997, 63, 3261-3267.

44. Pernthaler, J.; Pernthaler, A.; Amann, R. Automated enumeration of groups of marine picoplankton after fluorescence in situ hybridization. Appl. Env. Microbiol. 2003, 69, 2631-2637. [CrossRef]

45. Langendijk, P.S.; Schut, F.; Jansen, G.J.; Raangs, G.C.; Kamphuis, G.R.; Wilkinson, M.; Welling, G.W. Quantitative fluorescence in situ hybridization of bifidobacterium spp. With genus-specific 16s rrna-targeted probes and its application in fecal samples. Appl. Env. Microbiol. 1995, 61, 3069-3075.

46. Garini, Y.; Gil, A.; Bar-Am, I.; Cabib, D.; Katzir, N. Signal to noise analysis of multiple color fluorescence imaging microscopy. Cytom. J. Int. Soc. Anal. Cytol. 1999, 35, 214-226. [CrossRef]

47. Zhou, Z.; Pons, M.N.; Raskin, L.; Zilles, J.L. Automated image analysis for quantitative fluorescence in situ hybridization with environmental samples. Appl. Env. Microbiol. 2007, 73, 2956-2962. [CrossRef]

48. Thomas, L.; Gidding, H.; Ginn, A.; Olma, T.; Iredell, J. Development of a real-time staphylococcus aureus and mrsa (sam-) pcr for routine blood culture. J. Microbiol. Methods 2007, 68, 296-302. [CrossRef] [PubMed] 